\title{
若年者に括ける頭頸部悪性腫瘍症例の検討
}

\author{
梅野 博化・松田 洋一・森 一功* \\ 千々和圭一・梅野 哲義・中島 格
}

\section{A Clinical Study of Malignant Head and Neck Tumors in Juvenile Patients}

\author{
Hirohito Umeno, Youichi Matsuda, Keiichi Chijiwa, \\ Tetsuyoshi Umeno and Tadashi Nakashima \\ (Kurume University) \\ Kazunori Mori \\ (Kinki University)
}

\begin{abstract}
Twenty patients under 20 years old age with malignant head and neck tumors were treated at Kurume University Hospital between 1979 and 1998. There were eight males and twelve females and the mean age was 14 years old. Histologically, rhabdomyosarcoma and papillary carcinoma were observed in 5 patients, squamous cell carcinoma in 4 patients, neuroblastoma and malignant lymphoma in 2 patients, and Langhans cell histiocytoma and leiomyosarcoma in 1 patient. Their 5 -year survival rate was $82.6 \%$. Team practice is required to treat juvenile patients with malignant head and neck tumors.
\end{abstract}

Key words : malignant head and neck tumor, juvenile, histology, survival rate

\section{緒言}

頭頸部領域に括ける小児を含めた若年者の悪性腫瘍は, その発生頻度の低さとその特殊性のため治療に難橴する ことが多い：今回われわれは，1979～1998年の 20 年間に 当科と当院小児科扣よび放射線科で集学治療を行った 20 歳以下の若年者頭頸部領域覀性腫瘍20症例を対象に, 組 織型ごとの治療方法とその経過および治療成績を検討し た.

\section{対 象}

1979 1998年に当科で治療を行った頭頸部悪性腫瘍は 2, 426例あり，そのなかで小児を含めた 20 歳以下の若年 例は 20 例(男性 8 人，女性 12 人)で，全体の $0.8 \%$ を占め
ていた．年齢分布は $1 \sim 20$ 歳(平均14歳)であり, 生存例 の平均観察期間は70.9力月であった. 全症例の組織型の 内訳は横紋筋肉腫が 5 例, 乳頭癌が 5 例, 扁平上皮癌が 4 例, 神経芽細胞腫が 2 例, 悪性リンパ腫が 2 例, ラン グハンス細胞組織球腫が 1 例, 平滑筋肉腫が 1 例であっ た. それぞれの原発部位は, 横紋筇肉腫では中咽頭が 2 例, 鼻・副鼻腔が 2 例, 副咽頭間腺が 1 例であり, 乳頭 癌は全例が甲状腺原発であった。扁平上皮癌は全例が上 咽頭原発であり, 神経芽細胞腫は 2 例とも鼻腔原発で あった．悪性リンパ腫は 2 例とも中咽頭が原発であり, ラングハンス細胞組織球腫と平滑笳肉腫は側頭下窩が原 発であった。 


\section{治療経過と成績}

組織型ごとの治療経過を示す．横紋筋肉腫症例の治療 方法は化学療法と手術と放射線治療の組及合わせが基本 となって招り(表 1), 中咽頭, 傍咽頭間隙, 篩骨洞原発 の 3 例がそれぞれ, 治療から15年 6 力月, 11年 4 力月, 2 年11カ月経過したが再発なく生存中である。しかしな がら, 中咽頭原発の 1 例は手術後化学療法を施行したが 3 年 3 力月後に腫瘍の頭蓋内浸潤で原発巣死した. 鼻腔 原発の 1 例は化学療法を施行した後に放射線治療を行っ たが治療前から胸椎と骨盤に広範な遠隔転移を認め，治
療から 1 年 5 カ月後に肺転移死した.

甲状腺乳頭癌症例は 1 例が手術後に頸部リンパ節転移 をきたしたが，頸部郭清術と残存甲状腺の摘出術を施行 し， 6 年 2 力月生存している(表 2 ). 他の 4 症例に括い ても全例手術の久を施行し, 非担癌生存している.

上咽頭扁平上皮癌症例は化学療法と放射線治療を行っ た 3 例は非担癌生存中であるが，両側頸部郭清術と放射 線治療のみを行った 1 例は 1 年 2 力月後に肺と骨の遠隔 転移で死亡した(表 3 ).

嗅神経芽細胞腫症例は手術と放射線治療を行い，5ち

表 1 横紋筋肉腫症例の治療と経過

\begin{tabular}{|c|c|c|c|c|c|c|c|}
\hline 年齢 & 性 & 原発巣 & 療 & 化 学 療 法 & 放射線線量 & 観察期間 & 経 過 \\
\hline 3 & 女 & 中咽頭 & ope + chemo + rad & $\mathrm{ADR}+\mathrm{VCR}+\mathrm{ACT}-\mathrm{D}+\mathrm{CPA}$ & $40 \mathrm{~Gy}$ & 15年 6 カ月 & 生存 \\
\hline 12 & 男 & 中咽頭 & ope + chemo & $\begin{array}{l}\mathrm{VCR}+\mathrm{ACT}-\mathrm{D}+\mathrm{CPA}+\mathrm{CDDP} \\
+\mathrm{ADR}+\mathrm{VP}-16\end{array}$ & - & 3 年 3 力月 & 原発巣死 \\
\hline 10 & 男 & 傍咽頭間隙 & chemo + ope + chemo & $\begin{array}{l}\mathrm{ADR}+\mathrm{CDDP}+\mathrm{ADR}+\mathrm{MTX} \\
\mathrm{DTIC}+\mathrm{MTX}\end{array}$ & - & 11年 4 カ月 & 生存 \\
\hline 13 & 男 & 篩骨洞 & chemo + rad + ope & $\mathrm{VCR}+\mathrm{ACT}-\mathrm{D}+\mathrm{CPM}+\mathrm{THP}$ & $50 \mathrm{~Gy}$ & 2 年11カ月 & 生存 \\
\hline 19 & 男 & 鼻腔 & chemo $+\mathrm{rad}$ & $\begin{array}{l}\mathrm{CPM}+\mathrm{VP}-16+\mathrm{ADR}+\mathrm{CPPD}+\mathrm{MTX} \\
+\mathrm{VCR}+\mathrm{ACT}-\mathrm{D}\end{array}$ & $51 \mathrm{~Gy}$ & 1 年 5 カ月 & 遠隔転移死 \\
\hline
\end{tabular}

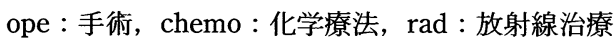

表 2 甲状腺乳頭癌症例の治療之経過

\begin{tabular}{c|c|c|c|c|c|c}
\hline \hline 年踹 & 性 & 1987年 TNM 分類 & 治 療 & 再発への治療 & 観察期間 & 経 過 \\
\hline 12 & 女 & T3N1a & 半切+左頸部郭清術 & 全摘+右頸部郭清術 & 6 年 2 力月 & 生存 \\
\hline 19 & 女 & T2N0 & 半切+左頸部郭清術 & - & 10 年 3 力月 & 生存 \\
\hline 19 & 女 & T3N1b & 全摘 & - & 5 年 4 力月 & 生存 \\
\hline 20 & 女 & T2N0 & 半切 & - & 12 年11力月 & 生存 \\
\hline 20 & 女 & T1N1b & 全摘+両頸部郭清術 & - & 1 年 4 力月 & 生存
\end{tabular}

表 3 上咽頭扁平上皮癌症例の治療と経過

\begin{tabular}{|c|c|c|c|c|c|c|c|}
\hline 年齢 & 性 & 1987年 TNM 分類 & 療 & 化 学 療 法 & 放射線線量 & 観察期間 & 経 過 \\
\hline 18 & 男 & T3N2C & chemo+rad & $\mathrm{CDDP}+5 \mathrm{FU}$ & $71 \mathrm{~Gy}$ & 3 年 8 力月 & 生存 \\
\hline 15 & 女 & T3N3 & ope (両側頸部郭清術) +rad & - & $50 \mathrm{~Gy}$ & 1 年 2 力月 & 遠隔転移死 \\
\hline 16 & 女 & $\mathrm{T} 3 \mathrm{~N} 1$ & chemo+rad & $\mathrm{CDDP}+5 \mathrm{FU}$ & $60.5 \mathrm{~Gy}$ & 3 年10力月 & 生存 \\
\hline 17 & 男 & T2N3 & chemo $+\mathrm{rad}+$ chemo & $\begin{array}{l}\mathrm{CDDP}+\mathrm{PEP} \\
\mathrm{CDDP}+\mathrm{PEP}+5 \mathrm{FU}+\mathrm{ADR}\end{array}$ & $70 \mathrm{~Gy}$ & 9 年 & 生存 \\
\hline
\end{tabular}

ope : 手術, chemo : 化学療法, rad : 放射線治療 
表 4 嗅神経芽細胞腫症例の治療之経過

\begin{tabular}{|c|c|c|c|c|c|c|c|}
\hline 年歯 & 性 & 原発巣 & 療 & 化学療法 & 放射線線量 & 観察期間 & 経 過 \\
\hline 19 & 男 & 嗅裂 & ope $+\mathrm{rad}+$ chemo & $\mathrm{CDDP}+\mathrm{PEP}$ & $50 \mathrm{~Gy}$ & 4 年 2 力月 & 生存 \\
\hline 19 & 女 & 嗅裂 & ope + rad & - & $61 \mathrm{~Gy}$ & 4 年 3 力月 & 生存 \\
\hline
\end{tabular}

ope : 手術, chemo：化学療法, rad : 放射線治療

表 5 悪性リンパ腫症例の治療之経過

\begin{tabular}{c|c|c|c|c|c|c}
\hline \hline 年齢 & 性 & 原発巣 & 治 療 & 化学療法 & 観察期間 & 経 過 \\
\hline 2 & 女 & 扁桃 & chemo & 詳細不明 & 1 年10 月 & 消息不明 \\
\hline 15 & 男 & 扁桃 & chemo & VCR + ADR $+C P M+M T X$ & 4 年 2 力月 & 生存 \\
\hline
\end{tabular}

chemo:化学療法

1 例は化学療法も追加した. 2 例とも再発なく生存中で ある(表 4 ).

悪性リンパ腫症例は 2 例とも化学療法を施行し, 1 例 は再発なく生存中であるが，1例は再発ないまま消息不 明となっている(表 5).

1 歳女児のラングハンス細胞組織球腫症例は化学療法 (VP16+VLB) を行い, 治療から 2 年後には再発はなかっ たが，その後に追跡不能となっている。

20 歳男性の平滑筋肉腫症例は化学療法之手術之放射線 治療を行い, 治療後 2 年経過したが, 再発なく生存中で ある。

これら20症例全体の治療成績を Kaplan-Meier 法で算 出すると，死因特異的 5 年累積生存率は $82.6 \%$ であった. 治療成績がよい甲状腺癌を除く 15 例では75.0\%であった。 また，横紋篎肉腫や神経芽細胞腫などの非上皮性腫瘍 11 例では75.8\%, 乳頭癌, 扁平上皮癌の上皮性腫瘍 9 例で は88.9\%であった。

ここで20歳男性の平滑筋肉腫症例を, 耳鼻咽喉科, 小 児科, 放射線科との集学治療が奏功した典型例として提 示する。

\section{症例}

症例 : 20歳, 男性.

主訴: 右眼球突出, 右下顎のしびれ感.

現病歴：1998年 6 月上旬より右眼球突出を自覚し, 某 眼科を受診した。同院で眼球に異常は認められず，右下 䪽と右煩部のしびれ感も出現していたため某耳萛咽喉科
を受診. 同院で MRI 検査により右側頭下窩の腫瘍を指 摘され，当科を紹介の上，1998年 7 月 1 日入院となった.

入院時所見と経過：入院時, 右眼の眼球突出と右三叉 神経第 2,3 枝領域の知覚鈍麻を認めた。 入院時の MRI (水平断：図 1, 環状断：図 2) 示す。腫瘍は右側頭窩 から側頭下窩に主座し, 右中頭蓋底, 右眼窩内への浸潤 がみられ，右視野欠損が認められた。1998年 7 月 8 日,

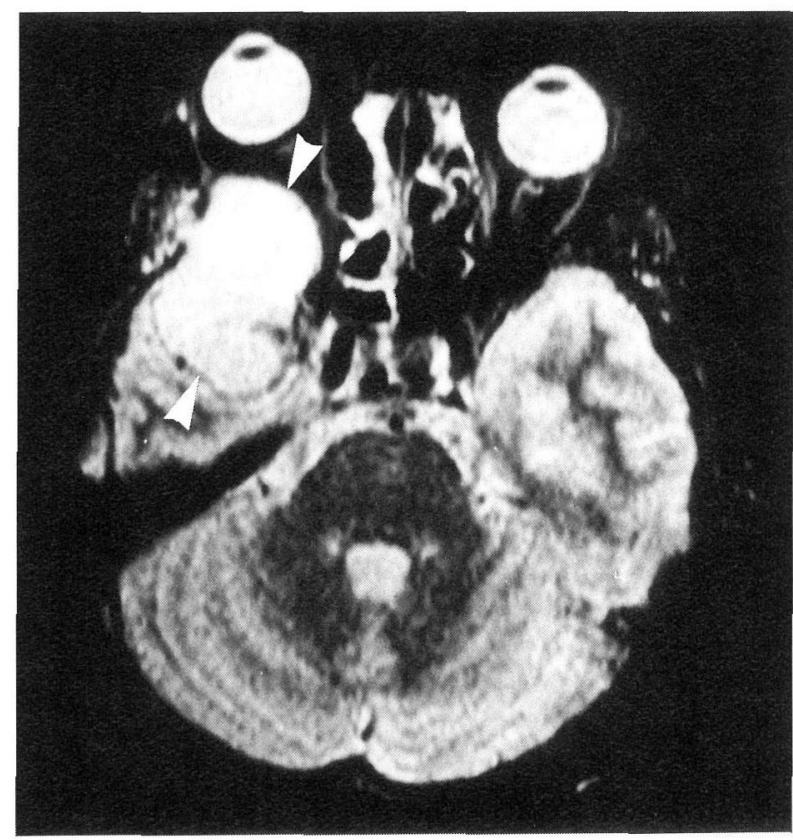

図 1 水平断 MRI (STIR 像, 腫瘍部分を矢印で示す) 右中頭蓋底，右眼窩内への腫瘍浸潤がみられる。 


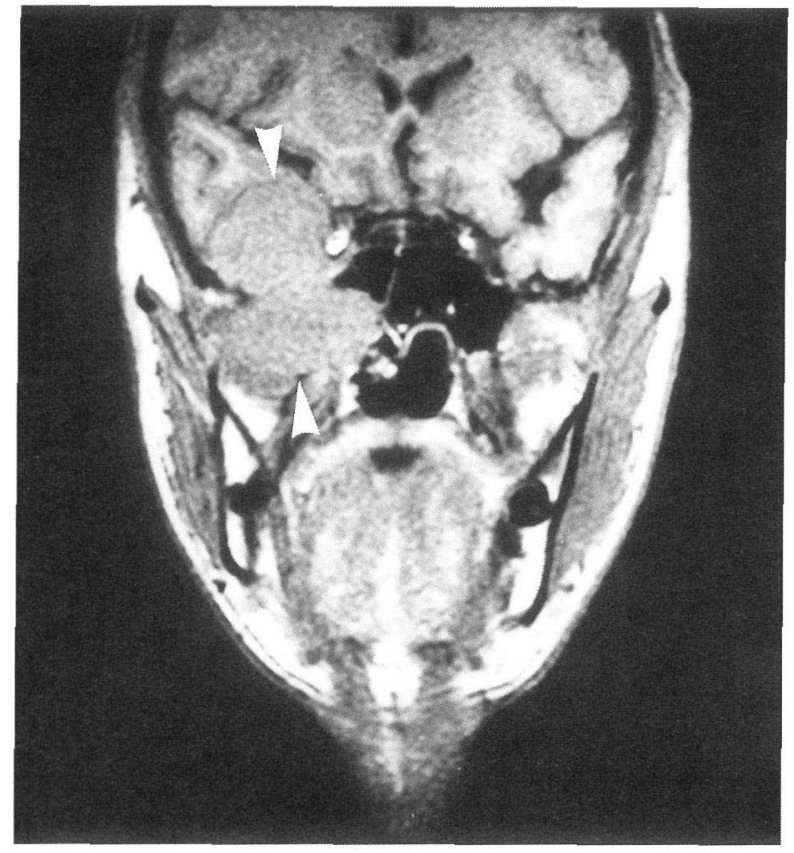

図 2 環状断 MRI ( $\mathrm{T} 1$ 強調像, 腫瘍部分を矢印で示す) 腫瘍は右側頭窩から側頭下窩に主座し, 右中頭蓋底への 浸潤がみられる。

犬歯窩より切開を加兄, 経上靧洞的に腫瘍生検を行った. 組織䛦断の結果は平滑筋肉腫であったため，当院小児科 転科の上，化学療法 (VP-16+CBDCA+L-PAM) を3. 5 クール施行した。化学療法終了後の1999年 2 月 22 日, 全 身麻酔下に側頭下窩腫瘍摘出術を施行した。皮切は頭部 環状切開加光頓骨弓を切除し, 外側翼突笳深部の腫瘍 を切除した。術後, 小児科で再度化学療法を 1 クール施 行した後, 未梢血幹細胞移植を行った。 その後1999年 5 月 6 日上り局所飞 $50 \mathrm{~Gy}$ 放射線治療を行い, 現在 2 年 6 カ月を経過したが腫瘍の再発は認めていない。

\section{考察}

頭頸部悪性腫瘍のうち小览の占める率は全体の0.5 $1 \%$ といわ秃て扣り1), 当科でも全体の $0.8 \%$ と矢の発 生頻度は低かった。

各組織型に対する年齢分布には特徴がみられ，横紋筋 肉腫は $3 \sim 19$ 歳まで幅広く発症して稿り, 悪性リンパ腫 も同様に 2 歳と15歳にみられた。乙かし, 乳頭癌は12歳 が 1 例のほかは19歳と 20 歳に 2 例ずつと, 10 代後半に多 くみられた。扁平上皮癌も15１8歳をでの10代後半にみ られ, 神経芽細胞腫, ラングハンス細胞組織球腫, 平滑
筋肉腫も同様に10代後半にみられた.

若年者悪性腫瘍を上皮性々非上皮性に分類すると，岸 本ら2) はそ治療成績に差がなかったと報告しているが， 野々村ら ${ }^{3)}$, 上田ら ${ }^{4)}$ は非上皮性の方が上皮性上り治療 成績が悪かったと報告している，当科の治療成績でも非 上皮性の方が上皮性より治療成績が悪い傾向がみられた。 以降，組織別飞考察する。

横紋筋肉腫は小児悪性腫瘍の 4 〜 8\%を占める小児期 の最も頻度が高い軟部腫瘍であり5), 当科でも乳頭癌と ともに高頻度であった。横紋筋肉腫の治療は小児科との タイアップが必要であり, VAC 療法 (VCR, ACT-D, CPM) を中心とした化学療法が標準である。しかし， 1993年からは厚生省班会議プロトコールにより, 化学療 法, 外科療法, 放射線療法で残存腫瘍細胞を最小限に乙 た後，自家骨髄移植，または末梢血幹細胞移植を用いた 超大量化学療法を行い, 腫瘍の根治を目指す方法が取り 入れられている. 当科でも化学療法, 外科療法, 放射線 療法艺行った 2 症例は生存して赫り, 外科療法と化学療 法, 屯たは化学療法と放射線療法しか施行でさなかった 3 症例のらち 2 症例は原病死している。肾に誩ける頭 頸部領域の横紋筋肉腫は, 耳鼻咽喉科, 小览科, 放射線 科との集学治療を行うことが肝要と再認識させられた。

若年者の乳頭癌は成人之同様に，手術で根治が十分可 能な症例が多く, これ屯での諸家の報告と同様であっ $\star^{6}$.

若年者の上咽頭扁平上皮癌は成人ょり進行癌で発見さ れる場合が多い7). 当科でも同様に初診時すでに 4 例中 3 例が $\mathrm{T} 3$ 症例であり, ほかの 1 例も $\mathrm{T} 2 \mathrm{~N} 3$ 症例と進行 癌であった。 また，化学療法と放射線療法を行った症例 の経過は良好であったが，手術と放射線療法の久を施行 した症例は遠隔転移死していた。最近では遠隔転移の予 防で補助化学療法を $4 \sim 8$ ニース行ら報告も灭られ8), 化学療法の必要性が明白となった。

嗅神経芽細胞腫は嗅粘膜上皮由来の比較的子れな悪性 腫瘍であるが, Lindstrom ら ${ }^{9}$ は嗅神経芽細胞腫の好発 年齢には11〜20歳と31〜40歳の 2 つピークがあると報 告して和り, 若年者に物いても十分注意を要する悪性腫 瘍である。一般に本腫瘍は放射線感受性が高いことから， 放射線と手術療法の併用が行われている10111). 本症例で は放射線と手術療法に加克, 1 例にシスプラチンを基礎 とした化学療法を行ったが 2 例とも再発は認めていない. しかし，化学療法に関して明確なプロトコールは確立さ 


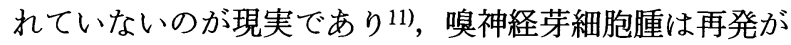
治療終了後 5 年以上経過して起こり得ることが報告され ている12)。われわれも成人の嗅神経芽細胞腫症例で 12 年 後に再発した症例を経験して括り, 長期フォローアップ の必要性を強調したい。

小児の悪性リンパ腫は成人と異なり，リンパ節以外に 発生しやすい特徵があるといわれて扣り ${ }^{13)}$, 当科での 2 症例とも口蓋扁桃が原発であった．最近の小児悪性リン パ腫の治療成績は化学療法の進歩に伴って著しく向上し て拈り，化学療法による副作用の軽減に心血が注がれる 傾向にある14)。

ラングハンス細胞組織球腫は従来は histiocytosis-X と呼ばれていた疾患で, 中枢神経系では視床下部, 漏斗 部などに肉芽を形成する. 頭蓋底の骨病変からこの部に 肉芽腫が波及するものもあり, 当科での症例はこのタ イプと考兄られた. ラングハンス細胞組織球腫は Gagel's granuloma との別名もあり, 小児, 若年成人に多い15). 当科での症例は追跡不能であり, その経過が不明な点が 残念である.

平滑笳肉腫は子宮, 膀胼, 消化管に多くみられ, 頭頸 部領域の発生はまれである. 頭頸部原発のほとんどは鼻・ 副鼻腔領域に発生して扣り, 当科の症例は側頭下窩が原 発であった. 平滑笳肉腫は一般に予後不良であり, 治療 は広範囲切除が不可欠と考它られている. しかし, 若年 者では広範囲切除施行が術後の QOL を著しく下げてし まらことが大きな問題となる，当科の症例は, 幸い当科 と小児科, 放射線科との集学治療を行うことで QOLを 下げることなく初期治療を完了し得た代表例と考兄られ た. しかし，小児を含めた若年者では放射線治療後の骨 発育不全, 下垂体ホルモン分泌不全による発育障害, 放 射線誘発性 2 次癌といった照射後の合併症が問題とな る16). 化学療法では, 骨髄抑制に伴う重症感染症, 消化 器症状， 2 次発癌の危険性を考慮しなければならない。 また，身体的のみならず精神的苦痛への配慮も必要であ り, 耳鼻咽喉科 - 頭頸部外科, 小児科, 放射線科以外飞 も内科, 精神科, 産婦人科, 泌尿器科などを含めたチー ム治療が要求される34). いずれにせよ, 晚期の合併症 にも十分な配慮が必要なため, 治療後は長期の経過観察 が必要と考兄られた。

\section{まとめ}

1. 1979 1998年の 20 年間に当科と当院小児科执よび
放射線科で集学治療を行った 20 歳以下の若年者に発症し た頭頸部領域悪性腫瘍20症例を対象に，組織型ごとの治 療方法とその経過执よび治療成績を検討した.

2 . 全症例の組織型の内訳は横紋筋肉腫が 5 例, 乳頭 癌が 5 例, 扁平上皮癌が 4 例, 神経芽細胞腫が 2 例, 悪 性リンパ腫が 2 例, ラングハンス細胞組織球腫が 1 例, 平滑筋肉腫が 1 例であった。

3 . 全 20 症例全体の 5 年累積生存率は $82.6 \%$ であり, 非上皮性腫瘍 11 例では $75.8 \%$, 上皮性腫瘍 9 例では 88.9 \%であった。

本論文の要旨は第 62 回耳鼻咽喉科臨床学会 (平成 12 年 7 月, 福井市)と打いて口演した。

\section{参考文献}

1) 小野 勇 : 小児の頭頸部悪性腫瘍. 小児科 MOOK No 45 (馬昜一雄, 小林 登編). $218 \sim 224$ 頁, 金原出版, 東京, 1986.

2 ）岸本誠司, 斉川雅久, 海老原敏, 他 : 頭頸部悪性腫瘍. 頭 頸部外科 $9: 41 \sim 47,1999$.

3 ）野々村直文, 五十嵐文雄, 川名正博, 他 : 若年者頭頸部悪 性腫瘍の検討. 耳喉頭頸 $65: 579 \sim 582,1993$.

4 ）上田直之, 福島典之, 長谷川淳一, 他 : 当科に打ける若年 者頭頸部悪性腫瘍の検討. 耳鼻臨床 補 $102: 70 \sim 75,1999$.

5 ) 杉本 徹, 細井 創, 松村隆文, 他 : 小児の頭頸部横紋筋 肉董. JOHNS $17: 971 \sim 977,1998$.

6 ) Yasumoto K, Miyagi C, Nakashima T, et al : Papillary and follicular thyroid carcinoma ; the treatment result of 357 patients at the National Kyusyu Cancer Centre of Japan. J Laryngol Otol $110: 657 \sim 662,1996$.

7 ) Ingersoll L, Woo SY, Donaldson S, et al : Nasopharyngeal carcinoma in the young; a combined MD Anderson and Stanford experience. Int J Radiat Oncol Biol Phys 19 : $881 \sim 887,1990$.

8 ) 高橋久昭, 鎌田信悦, 川端一嘉, 他 : 上咽頭癌の補助化学 療法の有効性. 日耳鼻 $99: 267 \sim 276,1996$.

9 ) Lindstrom CG and Lindstrom DW : Olfactory neuroblastoma. Acta Otolaryngol $80: 447 \sim 451,1975$.

10）中川暁子, 瀬成田雅光, 高橋和彦, 他 : 嗅神経芽細胞腫の 2 例. 耳展 $42: 52 \sim 57,1999$.

11）海沼和幸, 石山哲也, 後藤昭信, 他 : 神経芽細胞腫の 3 症 例. 耳鼻臨床 $90: 417 \sim 423,1997$.

12) Olsen KD and Desanto LW : Olfactory neuroblastoma ; biologic and clinical behavior. Arch Otolaryngol 109 : 797 802, 1983.

13）日比成美, 澤田 淳 : 小児の悪性リンパ腫. JOHNS 14 ： 
979 982, 1998.

14) Link MP, Shuster JJ, Donaldson SS, et al : Treatment of children and young adults with early-stage non-Hodgkin's lymphoma. N Eng J Med 337 : 1259 1266, 1997.

15) 中里洋一: 中枢神経系. 外科病理学(石川栄世, 遠城寺宗 知編). 1347 1406頁, 文光堂, 東京, 1999.

16）恒松由記子：小児悪性腫瘍の晚期障害と二次発癌. 小児医
学の進歩． '91B 新小児医学大系(小林 登編). $279 \sim 293$ 頁, 中山書店, 東京, 1991.

$$
\left.\begin{array}{l}
\text { 原稿受付 : 平成 } 13 \text { 年 } 1 \text { 月 } 4 \text { 日 } \\
\text { 原稿採択 : 平成 } 13 \text { 年 } 2 \text { 月 } 7 \text { 日 } \\
\text { 別刷請求先 : 梅野博仁 } \\
\text { T } 830-0011 \text { 久留米市旭町 } 67 \\
\text { 久留米大学医学部耳鼻咽喉科学講座 }
\end{array}\right)
$$

